\title{
Article \\ Quantitative Comparison between Traditional and Intensive Face-to-Face Education through an Organizational Model
}

\author{
Cristina Checa-Morales ${ }^{1,2,3}{ }^{\text {, Carmen De-Pablos-Heredero }}{ }^{4} \mathbb{D}$, Yenny Guiselli Torres ${ }^{5}$, Cecilio Barba ${ }^{3} \mathbb{D}$ \\ and Antón García ${ }^{3, * \text { (D) }}$ \\ 1 International Doctoral School (EID), Rey Juan Carlos University, 28008 Madrid, Spain; \\ c.checa.2019@alumnos.urjc.es \\ 2 Department of Business Economics (ADO), Rey Juan Carlos University, 28032 Madrid, Spain; \\ carmen.depablos@urjc.es \\ 3 Animal Science Department, Rabanales Campus, University of Cordoba, 14071 Cordoba, Spain; \\ cjbarba@uco.es \\ 4 Business Organization/Faculty of Business, Area of Business Economics, ESIC University, \\ 28223 Madrid, Spain \\ 5 Quevedo State Technical University, Carlos J. Arosemena Av., Quevedo 120301, Ecuador; ytorres@uteq.edu.ec \\ * Correspondence: pa1gamaa@uco.es
}

check for updates

Citation: Checa-Morales, C.; De-Pablos-Heredero, C.; Torres, Y.G.; Barba, C.; García, A. Quantitative Comparison between Traditional and Intensive Face-to-Face Education through an Organizational Model. Educ. Sci. 2021, 11, 820. https:// doi.org/10.3390/educsci11120820

Academic Editors: Hava E. Vidergor and Randall S. Davies

Received: 4 November 2021

Accepted: 15 December 2021

Published: 18 December 2021

Publisher's Note: MDPI stays neutral with regard to jurisdictional claims in published maps and institutional affiliations.

Copyright: (c) 2021 by the authors. Licensee MDPI, Basel, Switzerland. This article is an open access article distributed under the terms and conditions of the Creative Commons Attribution (CC BY) license (https:/ / creativecommons.org/licenses/by/ $4.0 /)$.

\begin{abstract}
Face-to-face education continues to present benefits in terms of student motivation, even though in COVID-19 scenario, online education has been the model of choice. In addition to the traditional face-to-face style, the intensive face-to-face style remains, which allows greater flexibility for the student. The objective of this study was to compare both educational styles and build an organizational model to improve student satisfaction. Two-way general linear model (GLM) with educational styles and satisfaction as fixed factors and discriminant analysis was applied. The selection of the most discriminant variables was made applying the F of Snedecor, Wilks'-Lambda, and the 1-Tolerance. A discriminant model was built. The four variables with the highest discriminant power were problem-solving communication with students' representatives and shared knowledge and goals with lectures in the intensive style and frequent communication with administrative officers in the traditional style. In addition, it was found that greater face-to-face attendance did not imply greater coordination and that intensive style students show greater satisfaction. The appropriate duration of face-to-face education can contribute to the design of an innovative hybrid system in the future.
\end{abstract}

Keywords: relational coordination model; higher education; discriminant analysis; improvement of the education system

\section{Introduction}

The COVID-19 crisis caused a paradigm shift in education [1], with a necessary establishment of online education during the confinement period. Nowadays, there is a tendency to establish hybrid learning systems permanently [2]. However, face-to-face education is the most successful model [2,3]. This modality has been coexisting with others that try to satisfy a demand whose profile did not meet the demands of face-to-face education (blended education, online, etc.) [3-6]. In addition, to satisfy part of that demand, different styles of attendance were observed.

Traditional face-to-face education (TFE) was defined by Gherheș et al. [7] as "an instructional method where course content and learning material are taught in person to a group of students". It has been the preferred educational strategy for students [7,8] and the most common educational method, where the student shares physical space with the professor and there is a continuous interaction between both profiles [5]. The duration of teaching is regulated in the EU by ECTS credits. One credit corresponds to 25 teaching 
hours, where $30-40 \%$ are face-to-face and $70-60 \%$ are non-face-to-face and correspond to the personal and group work of the student. Student- teacher interaction in the classroom allows immediate feedback $[3,9]$. It has been reported that face-to-face education has a lower dropout rate than other educational modalities [10]. In other types of education (distance, online, etc.), the lack of direct and accurate interaction with teachers causes a lack of motivation in students, in addition to higher rates of stress and anxiety [11]. TFE encourages participation in student interpersonal relationships and didactic communication [12]. As indicated by Cho et al. [13] and Gherheș et al. [7], motivation is directly linked to the degree of achievement of learning objectives.

TFE presents a lack of flexibility in class schedule for students who need to reconcile their academic and professional life $[3,5,14]$. This can generate anxiety patterns in students [15] and especially affects students with a job [16] or family responsibilities [17,18]. According to Sprung and Rogerts [15], the balance between personal and professionaleducational life is an important antecedent of mental health of university students, and educational institutions should facilitate this balance to improve the university experience. An organizational improvement in the management of work-study reconciliation by the institution is reflected in an improvement in academic results [14].

Intensive education is a variant of traditional face-to-face education. This style concentrates the teaching hours in compressed periods of time [17-20]. The credit has the same duration as in the TFE $(25 \mathrm{~h})$, although the percentage of face-to-face attendance of the students is lower, with a variable term between $10-30 \%$ of the time. [21]. Given the growing demand of students for a model of these characteristics, some universities offer intensive face-to-face education programs (IFE) to allow non-conventional students to opt for face-to-face education $[13,16-18,20,22,23]$. The intensive academic day generally covers $8 \mathrm{~h}$ a day $[18,23]$ and includes all the training contents of the subject $[17,18,23]$. Therefore, the component of student attendance decreases, but without being eliminated, considering it a modality or educational style within face-to-face education $[19,24,25]$. The IFE student profile is different from that of the TFE. In the traditional style, there are mostly young students who have just finished secondary education and do not have family responsibilities [26]. On the contrary, in the intensive style, the students that make their education compatible with their job predominate $[7,16,27]$. They are generally older people who financially support their family [17]. According to Cho et al. [13], granting a greater degree of autonomy to students allows higher levels of motivation. While in the TFE the student dedicates most of the total amount of learning hours to attending master classes, the IFE is characterized by the dedication to independent work of the student outside the institution most of the time. In other words, the self-activity of the student predominates in the intensive learning process, dedicating only a part to attending classes or mentorship where the professor solves specific doubts [24].

Therefore, in the IFE the self-regulated learning of the students becomes important [28-30]. According to Romero et al. [28], this educational style is associated with higher levels of student resilience and better academic results. The compressed schedule enhances the self-discipline [8] and the assimilation of knowledge [30]. Furthermore, according to Hsu et al. [29], greater autonomy in the learning process contributes directly to the employability later.

The implementation of a learning style such as the IFE must take into account organizational coordination, since the same training contents as in the TFE must be taught in less time [5]. Relational coordination (RC) plays a crucial role in the educational strategy [1]. $\mathrm{RC}$ is an organizational model for the integration of tasks, based on the dimensions of communication and relationship among the stakeholders of the organization $[4,5,31-33]$. Accurate, frequent, and problem-solving communication defines the first dimension of the model $[31,32]$. These characteristics allow the establishment of strong links in contexts with high levels of tasks' interdependence [32,33]. Shared goals and knowledge and mutual respect constitute the second dimension $[31,32,34]$. These elements allow the sharing of relevant information for the decision making process [32,33]. 
The RC model has been studied in sectors such as banking [35], airlines [34], health [4,31], and entrepreneurship [33], showing that a higher level of RC significantly increases the quality of the organization's results, regardless of the sector. Furthermore, RC has been applied to higher education. In the online mode, Gallego et al. [4] and Margalina et al. [36] highlighted the importance of communication and its relationship with quality, by studying two Spanish universities. In the face-to-face mode, De-Pablos-Heredero et al. [37] showed the relationship between $\mathrm{RC}$ and educational quality, through the construction of an organizational model by means of a transnational comparison, proving how an increase in RC allows students to achieve a higher level of student satisfaction.

The objective of this work was to compare the traditional face-to-face (TFE) and intensive (IFE) styles through a quantitative model. The effect of coordination on educational style and student satisfaction was studied. A two-stage study was conducted. In a first stage, organizational and satisfaction differences were determined individually using general linear models (GLM). In a second stage, a discriminant model that differentiated both styles of face-to-face education was built, combining educational style and satisfaction. The comparison of the traditional and intensive style contributes to improving the satisfaction performance of the face-to-face educational modality. This would be a first step in building efficient hybrid educational systems through the implementation of coordination variables. The evaluation of this effect requires an environment where both styles coexist, as is the case of the Quevedo State Technical University (UTEQ).

There is a social responsibility of the institutions to offer quality training styles appropriate to each student profile [16-18] and to promote more efficient and innovative educational methods $[1,38]$. There is a lack of quantitative research that compares faceto-face education [7] and identifies its organizational and collaborative elements [12]. Therefore, the following research questions were raised: RQ1) Is greater face-to-face assistance associated with greater coordination? RQ2) Is greater student satisfaction associated with greater coordination? RQ3) Is it possible to build an organizational model through $\mathrm{RC}$ variables?

After this introduction, the second section presents the sample and the statistical methods used; the third section collects the research results; the fourth, the discussion of them; the fifth, the limitations of the study; and, finally, the sixth section shows the main conclusions of this research.

\section{Materials and Methods}

\subsection{Quevedo State Technical University (UTEQ)}

Quevedo State Technical University (UTEQ) is an Ecuadorian public university located in the city of Quevedo, Los Ríos province [39]. It has been accredited as "B" category by the Council for the Evaluation, Accreditation, and Quality Assurance of Higher Education of Ecuador (CEACEES), on a scale from A to D, according to decreasing quality criteria, and it has been studied as an organizationally sustainable higher education institution [40]. According to CEAACES, Ecuadorian legislation determines its academic offer according to "relevance", that is, according to local, regional, and national development needs [41].

The UTEQ offers its degrees in both traditional face-to-face (TFE) and intensive (IFE) educational styles, with the same professors and training content. TFE is taught from Monday to Friday, with a duration of 6 teaching hours per day ( $30 \mathrm{~h}$ per week), while the IFE concentrates the same training content on two days, Saturday and Sunday, where students attend the educational centre $8 \mathrm{~h}$ a day (16 h a week).

\subsection{Data Collection and Survey}

The data came from a database composed of more than 4000 pieces of information with students from first to fifth year, belonging to different degrees of animal sciences. Incomplete surveys and those that showed logical inconsistencies were eliminated by using the random function of the spreadsheet software [42]. To make up the complete database for this study, a random sample of 370 students from third to fifth year (170 from TFE and 
200 IFE) was taken, in the academic year 2018-2019 [43]. Degrees with an agri-food profile were selected due to the rural nature of growing economy of Ecuador [44]. To ensure objective answers about the evolution of the university, a minimum of three years of tenure in the educational centre was established. The students were asked through a survey. In conducting the survey, they were guided by a professor to avoid misinterpretation.

Regarding the structure of the survey, for the sociodemographic data, two variables were used: age and gender. In total, 29 items were used for the variables of the relational coordination model and for satisfaction [4,5,31,37]: 11 variables from the communication dimension, 12 from the relationship dimension, and 6 related to the level of student satisfaction. In the survey, students were asked for their degree of coordination with the rest of the university profiles and for their degree of satisfaction with each one (Table S1). Later on, each relational coordination variable was disaggregated into the following profiles: lecturers (Lect), administrative officers (Admin), classmates (Class), student representatives (Repres), and "myself" (Myself) as a control variable, that indicates the student's problem solving without the help of other profiles. The reliability of the survey was verified using Cronbach's alpha, with values greater than 0.7 , acceptable to confirm internal consistency: communication dimension (0.785), relationship dimension (0.889), and satisfaction (0.825). The complete survey showed a Cronbach's alpha of 0.906 [40,45]. The variables and the reliability values are shown in Table 1 . An ascending visual scale was used for the responses of the students, applying a Likert scale from 1 to 5 , from "infrequent" to "very frequent" [46]. The satisfaction metric was obtained from the cumulative level of student satisfaction, according to previous research $[37,40]$. A level of 21 points differentiated between two levels of satisfaction: low satisfaction (LS) with less than 21 points and high satisfaction (HS) with a score of 21 or higher (Figure 1).

Table 1. Relational coordination and satisfaction variables.

\begin{tabular}{|c|c|c|c|}
\hline Dimension & $\alpha$ Cronbach & Code & Question/Variable \\
\hline \multirow[t]{14}{*}{ COMMUNICATION } & 0.785 & \multicolumn{2}{|c|}{$\begin{array}{l}\text { ACCURATE COMMUNICATION: Do the people who belong to these areas have the } \\
\text { need to offer you information at certain times? }\end{array}$} \\
\hline & & 1. $\mathrm{ACCU}_{\mathrm{Admin}}$ & $\begin{array}{l}\text { Accurate communication with administrative } \\
\text { officers }\end{array}$ \\
\hline & & 2.ACCU Lect & Accurate communication with lecturers \\
\hline & & 3.ACCU $\mathrm{Alass}_{\text {}}$ & Accurate communication with classmates \\
\hline & & \multicolumn{2}{|c|}{$\begin{array}{l}\text { FREQUENT COMMUNICATION: Do people who belong to the following work areas } \\
\text { communicate with you frequently? }\end{array}$} \\
\hline & & 4.FREQ ${ }_{\text {Admin }}$ & $\begin{array}{l}\text { Frequent communication with administrative } \\
\text { officers }\end{array}$ \\
\hline & & 5.FREQ Lect & Frequent communication with lecturers \\
\hline & & 6.FREQ ${ }_{\text {Class }}$ & Frequent communication with classmates \\
\hline & & \multicolumn{2}{|c|}{$\begin{array}{l}\text { SOLVING PROBLEM COMMUNICATION: When any type of problem appears (study, } \\
\text { logistics, documentation, ... ), how much did the following profiles help you to solve } \\
\text { your problem? }\end{array}$} \\
\hline & & 7.SOLPRO ${ }_{\text {Myself }}$ & Problem-solving communication with myself \\
\hline & & 8.SOLPRO ${ }_{\text {Lect }}$ & Problem-solving communication with lecturers \\
\hline & & 9.SOLPRO Repres & $\begin{array}{l}\text { Problem-solving communication with students' } \\
\text { representatives }\end{array}$ \\
\hline & & 10.SOLPRO Admin $_{\text {S }}$ & $\begin{array}{l}\text { Problem-solving communication with } \\
\text { administrative officers }\end{array}$ \\
\hline & & 11.SOLPRO Class & Problem-solving communication with classmates \\
\hline
\end{tabular}


Table 1. Cont.

\begin{tabular}{|c|c|c|c|}
\hline Dimension & $\alpha$ Cronbach & Code & Question/Variable \\
\hline \multirow[t]{15}{*}{ RELATIONSHIP } & 0.889 & \multicolumn{2}{|c|}{$\begin{array}{l}\text { SHARED KNOWLEDGE: How well do the following profiles know your role in the } \\
\text { university and the problems that arise? }\end{array}$} \\
\hline & & 12.SKNOW Lect & Shared knowledge with lecturers \\
\hline & & 13.SKNOW Repres & Shared knowledge with students' representatives \\
\hline & & 14.SKNOW Admin $_{\text {SK }}$ & Shared knowledge with administrative officers \\
\hline & & 15.SKNOW Class & Shared knowledge with classmates \\
\hline & & \multicolumn{2}{|c|}{$\begin{array}{l}\text { MUTUAL RESPECT: How much do the following profiles respect your role at } \\
\text { the university? }\end{array}$} \\
\hline & & 16.RESPE Lect & Mutual respect with lectures \\
\hline & & 17.RESPE Repres & Mutual respect with students' representatives \\
\hline & & 18.RESPE ${ }_{\text {Admin }}$ & Mutual respect with administrative officers \\
\hline & & 19.RESPE $E_{\text {Class }}$ & Mutual respect with classmates \\
\hline & & \multicolumn{2}{|c|}{$\begin{array}{l}\text { SHARED GOALS: How well do the following profiles share your goals at } \\
\text { the university? }\end{array}$} \\
\hline & & 20.SHARGOAL Lect $_{1}$ & Shared goals with lecturers \\
\hline & & 21.SHARGOAL ${ }_{\text {Repres }}$ & Shared goals with students' representatives \\
\hline & & 22.SHARGOAL ${ }_{\text {Admin }}$ & Shared goals with administrative officers \\
\hline & & 23.SHARGOAL Class $_{\text {S }}$ & Shared goals with classmates \\
\hline \multirow[t]{7}{*}{ SATISFACTION } & 0.825 & \multicolumn{2}{|c|}{$\begin{array}{l}\text { STUDENT SATISFACTION: Indicate your degree of satisfaction with the } \\
\text { following profiles. }\end{array}$} \\
\hline & & 24.SATIS Lect & Satisfaction with lectures \\
\hline & & 25.SATIS Represent & Satisfaction with students' representatives \\
\hline & & 26.SATIS Admin $_{\text {. }}$ & Satisfaction with administrative officers \\
\hline & & 27.SATIS Materials & Satisfaction with materials \\
\hline & & 28.SATIS Communic $_{\text {. }}$ & Satisfaction with communication channels \\
\hline & & 29.SATIS Contents & Satisfaction with training contents \\
\hline
\end{tabular}

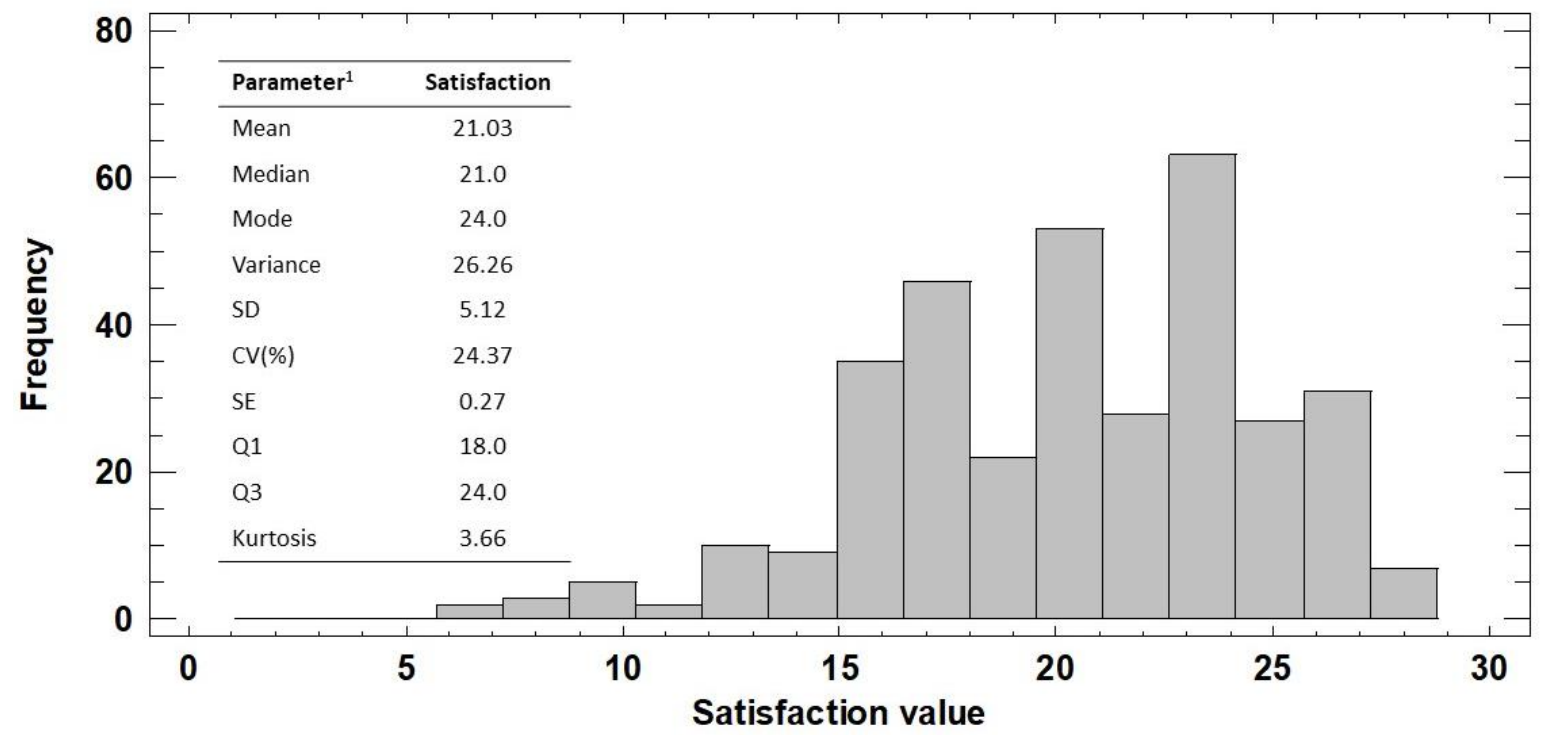

Figure 1. Statistical parameters of the student satisfaction value. 


\subsection{Statistical Analysis}

The normality of the data distribution was evaluated using the Kolmogorov-Smirnov test (with the Lilliefors correction) and a Levene test was used to evaluate the homogeneity of the variance. For those variables that did not show a normal distribution, the Bartlett test was applied to assess whether the data had equal variances.

In a first stage, to answer RQ1 and RQ2, the RC variables were compared using the general linear model (GLM). For this, two educational styles were used: traditional face-toface (TFE) and intensive face-to-face (IFE); and two levels of satisfaction: low satisfaction (LS) and high satisfaction (HS), as fixed factors. Three levels of significance were considered: ${ }^{*} p$-value $<0.05 ; * *$-value $<0.01$, and ${ }^{* * *} p$-value $<0.001$. This test allows the identification of significantly different means in the individual observation of the variables [47].

In a second stage, to answer RQ3, a discriminant analysis was performed [48]. To obtain the indicator of success in the classification, the proportional causality criterion described by Cea D'Ancona [49] was used, which accepts classification percentages that exceed by $25 \%$ the sum of the squares of the proportions of each group [49].

From the combination of the two fixed factors, four groups were obtained: TFE/LS, TFE/HS, IFE/LS, and IFE/HS. The most discriminating variables ( $p$-value $<0.05$ ) were calculated by applying Snedecor's F, Wilks's Lambda, and 1-Tolerance. The high values of $\mathrm{F}$ for each variable indicate that the means of each group are widely separated. The small Lambda values showed that the variable discriminates well between groups. Variables with a high percentage of tolerance (1-Toler) were selected [50]. Finally, the score of each discriminant variable in each group was determined. Statistical analyses were performed with STATISTICA 12 software.

\section{Results}

The average age of UTEQ students under 25 years of age was $49.46 \%$ of the sample. In TFE, students under 25 years of age predominated and in IFE, those over 25 ( $p$-value < 0.05 ). Regarding gender, most of the students were men in both educational styles ( $p$-value $<0.05$ ). The sociodemographic indicators of the sample are shown in Table 2.

Table 2. Sociodemographic distribution of the sample (\%).

\begin{tabular}{|c|c|c|c|c|c|c|}
\hline & \multicolumn{3}{|c|}{ Age } & \multicolumn{3}{|c|}{ Gender } \\
\hline & $\begin{array}{c}<25 \\
(n=183)\end{array}$ & $\begin{array}{c}\geq 25 \\
(n=187)\end{array}$ & $p$-Value & $\begin{array}{c}\text { Male } \\
(n=261)\end{array}$ & $\begin{array}{c}\text { Female } \\
(n=109)\end{array}$ & $p$-Value \\
\hline Traditional & 39.19 & 10.27 & $* * *$ & 28.11 & 17.84 & $* *$ \\
\hline Intensive & 6.76 & 43.78 & $* * *$ & 42.43 & 11.62 & $* *$ \\
\hline
\end{tabular}

The TFE style $(72.98 \pm 1.13 ; 0.2)$ showed lower than average RC levels than average (76.44 $\pm 0.83 ; 0.21)$, while the IFE style showed higher levels $(79.36 \pm 1.65 ; 0.21)$. Regarding satisfaction, the intensive style $(22.17 \pm 0.37 ; 0.24)$ obtained higher RC values than the mean $(21.03 \pm 0.27 ; 0.24)$, while the traditional style showed a lower level of RC $(19.68 \pm 0.35 ; 0.23)$.

The GLM results are shown in Table 3. Significant differences were found by educational style and level of satisfaction ( $p$-value $<0.05$ ). The two fixed factors showed no interactions ( $p$-value $<0.05$ ). Furthermore, $65.22 \%$ of the RC variables showed significant differences according to the educational style. The greatest differences were found in variables of problem-solving communication, mutual respect, and shared knowledge and goals, related to the profiles of lectures and student representatives. These variables showed higher levels of RC in IFE. Frequent communication with administrative officers showed higher levels of RC in TFE (Table 3). 
Table 3. Relational coordination by mode and satisfaction level.

\begin{tabular}{|c|c|c|c|c|c|c|c|}
\hline \multirow[b]{2}{*}{ Variable } & \multicolumn{2}{|c|}{ Educational Style } & \multicolumn{2}{|c|}{ Satisfaction Level } & \multicolumn{3}{|c|}{$p$-Value } \\
\hline & $\begin{array}{c}\text { Traditional } \\
\text { Face-to-Face }\end{array}$ & $\begin{array}{c}\text { Intensive } \\
\text { Face-to-Face }\end{array}$ & Low & High & $\begin{array}{c}\text { Educational } \\
\text { Style (A) }\end{array}$ & $\begin{array}{c}\text { Satisfaction } \\
\text { Level (B) }\end{array}$ & Interactions \\
\hline 1.ACCU $\mathrm{Admin}_{\mathrm{A}}$ & $3.25 \pm 0.10$ & $2.87 \pm 0.09$ & $2.72 \pm 0.11$ & $3.39 \pm 0.08$ & $* *$ & $* * *$ & ns \\
\hline 2.ACCU $\mathrm{Aect}$ & $3.82 \pm 0.06$ & $4.07 \pm 0.06$ & $3.70 \pm 0.07$ & $4.19 \pm 0.06$ & * & $* * *$ & ns \\
\hline 3.ACCU $\mathrm{Alass}_{\text {C }}$ & $3.83 \pm 0.07$ & $4.03 \pm 0.07$ & $3.75 \pm 0.08$ & $4.11 \pm 0.06$ & $*$ & $* * *$ & ns \\
\hline 4.FREQ ${ }_{\text {Admin }}$ & $2.62 \pm 0.10$ & $1.96 \pm 0.09$ & $1.91 \pm 011$ & $2.68 \pm 0.08$ & $* * *$ & $* * *$ & ns \\
\hline 5.FREQ & $3.54 \pm 0.08$ & $3.77 \pm 0.07$ & $3.37 \pm 0.09$ & $3.95 \pm 0.07$ & * & $* * *$ & ns \\
\hline 6.FREQ Class & $3.85 \pm 0.07$ & $3.98 \pm 0.07$ & $3.72 \pm 0.08$ & $4.11 \pm 0.06$ & ns & $* *$ & ns \\
\hline 7.SOLPRO ${ }_{\text {Myself }}$ & $4.31 \pm 0.06$ & $4.53 \pm 0.06$ & $4.36 \pm 0.07$ & $4.48 \pm 0.05$ & $* *$ & ns & ns \\
\hline 8.SOLPRO Lect & $3.01 \pm 0.08$ & $3.40 \pm 0.08$ & $2.80 \pm 0.09$ & $3.61 \pm 0.07$ & $* * *$ & $* * *$ & ns \\
\hline 9.SOLPRO Repres & $2.40 \pm 0.09$ & $3.26 \pm 0.08$ & $2.39 \pm 0.10$ & $3.27 \pm 0.08$ & $* * *$ & $* * *$ & ns \\
\hline 10.SOLPRO Admin & $2.41 \pm 0.09$ & $2.46 \pm 0.09$ & $1.99 \pm 0.10$ & $2.88 \pm 0.08$ & ns & $* * *$ & ns \\
\hline 11.SOLPRO Class $_{\text {San }}$ & $3.24 \pm 0.09$ & $3.27 \pm 0.09$ & $2.90 \pm 0.10$ & $3.61 \pm 0.08$ & ns & $* * *$ & ns \\
\hline 12.SKNOW & $3.00 \pm 0.08$ & $3.64 \pm 0.08$ & $2.95 \pm 0.09$ & $3.69 \pm 0.09$ & $* * *$ & $* * *$ & ns \\
\hline 13.SKNOW Repres & $2.54 \pm 0.09$ & $3.09 \pm 0.09$ & $2.87 \pm 0.10$ & $3.25 \pm 0.08$ & $* * *$ & $* * *$ & ns \\
\hline 14.SKNOW Admin $_{\text {Ad }}$ & $2.47 \pm 0.09$ & $2.33 \pm 0.09$ & $2.03 \pm 0.10$ & $2.77 \pm 0.08$ & ns & $* * *$ & ns \\
\hline 15.SKNOW & $3.45 \pm 0.09$ & $3.60 \pm 0.08$ & $3.37 \pm 0.10$ & $3.68 \pm 0.07$ & ns & $* *$ & ns \\
\hline 16.RESPE Lect & $3.42 \pm 0.07$ & $3.85 \pm 0.07$ & $3.31 \pm 0.08$ & $3.96 \pm 0.06$ & $* * *$ & $* * *$ & ns \\
\hline 17.RESPE Repres & $2.75 \pm 0.09$ & $3.26 \pm 0.09$ & $2.52 \pm 0.10$ & $3.50 \pm 0.08$ & $* * *$ & $* * *$ & ns \\
\hline 18.RESPE ${ }_{\text {Admin }}$ & $2.74 \pm 0.09$ & $2.55 \pm 0.09$ & $2.13 \pm 0.10$ & $3.16 \pm 0.08$ & ns & $* * *$ & ns \\
\hline 19.RESPE Class & $3.50 \pm 0.08$ & $3.68 \pm 0.07$ & $3.33 \pm 0.09$ & $3.85 \pm 0.07$ & ns & $* * *$ & ns \\
\hline 20.SHARGOAL Lect & $3.17 \pm 0.07$ & $3.76 \pm 0.07$ & $3.05 \pm 0.08$ & $3.88 \pm 0.06$ & $* * *$ & $* * *$ & ns \\
\hline 21.SHARGOAL Repres & $2.76 \pm 0.09$ & $3.24 \pm 0.08$ & $2.53 \pm 0.10$ & $3.47 \pm 0.07$ & $* * *$ & $* * *$ & ns \\
\hline 22.SHARGOAL ${ }_{\text {Admin }}$ & $2.56 \pm 0.09$ & $2.49 \pm 0.09$ & $2.02 \pm 0.10$ & $3.03 \pm 0.08$ & ns & $* * *$ & ns \\
\hline 23.SHARGOAL Class & $3.50 \pm 0.07$ & $3.73 \pm 0.07$ & $3.34 \pm 0.08$ & $3.88 \pm 0.06$ & $*$ & $* * *$ & ns \\
\hline
\end{tabular}

${ }^{*} p$-value $<0.05 ;{ }^{* *} p$-value $<0.01 ;{ }^{* * *} p$-value $<0.001 ;$ ns $=$ not significant.

In total, $95.65 \%$ of the variables showed significant differences according to satisfaction. The problem-solving communication related to the "myself" profile did not show differences. The rest of the RC variables exhibited higher levels of satisfaction (Table 3).

In order to identify the differences between educational styles, a discriminant analysis model was carried out. Four groups were built combining the two fixed factors: educational style and satisfaction. The groups were: traditional face-to-face education with low satisfaction (TFE/LS), traditional face-to-face education with high satisfaction (TFE/HS), intensive face-to-face education with low satisfaction (IFE/LS), and intensive face-to-face education with high satisfaction (IFE/HS). Furthermore, 59.89\% of the cases were correctly classified, so the validity of the model was verified, and $23 \mathrm{RC}$ variables were used as predictors. Six variables made up the discriminant model ( $p$-value $<0.05)$. Among the six variables, those four with the greatest discriminating power $(\mathrm{F}>5)$ were selected: two related to the communication dimension and two to the relationship dimension (Table 4). Frequent communication with administrative officers, problem-solving communication with students' representatives, and shared goals and knowledge with lectures were the variables with the highest discriminating power (Table 4).

Table 4. Discriminant function for the organizational variables of two educational styles (traditional face-to-face and intensive face-to-face).

\begin{tabular}{|c|c|c|c|c|c|c|}
\hline Variable & Wilks' & Partial & F-Remove & $p$-Value & Toler. & 1-Toler. \\
\hline 4.FREQAdmin & 0.484 & 0.941 & 7.341 & $* * *$ & 0.710 & 0.290 \\
\hline 9.SOLPRO & 0.478 & 0.953 & 5.823 & $* *$ & 0.632 & 0.368 \\
\hline 11.SOLPRO Class & 0.466 & 0.977 & 2.738 & * & 0.720 & 0.280 \\
\hline 12.SKNOW Lect & 0.475 & 0.958 & 5.148 & $* *$ & 0.685 & 0.315 \\
\hline 18.RESPE ${ }_{\text {Admin }}$ & 0.470 & 0.968 & 3.301 & $* *$ & 0.605 & 0.395 \\
\hline 20.SHARGOAL Lect & 0.480 & 0.948 & 6.478 & $* * *$ & 0.686 & 0.314 \\
\hline
\end{tabular}


The organizational differences among the four analysed groups are shown in Figure 2. The Mahalanobis distances obtained from the relational coordination indicators are graphically represented. A first cluster grouped TFE/LS and IFE/LS, a second cluster linked TFE/HS, and a third cluster was observed with IFE/HS.

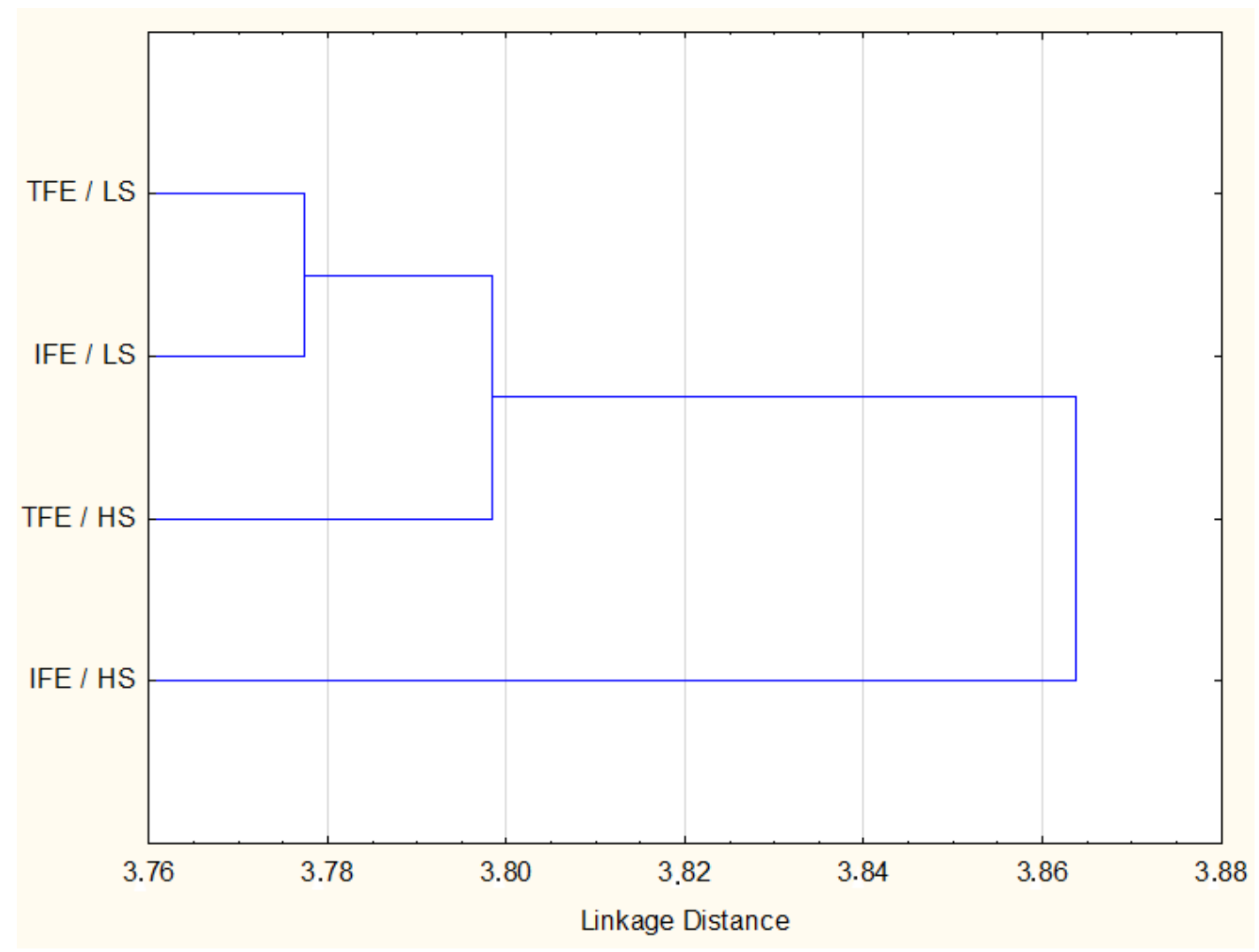

Figure 2. Cluster from Mahalanobis distances among the four groups.

Table 5 shows the scores of the discriminant variables for each group ( $p$-value $<0.001$ ). The two low-quality groups showed the lowest values in all variables. Frequent communication with the administration officers was the variable that stood out in the TFE/HS group. Finally, problem-solving communication with students' representatives and shared goals and knowledge with lectures were the variables that predominated in the IFE/HS group.

Table 5. Discriminant variables for each group.

\begin{tabular}{ccccc}
\hline & 4.FREQ $_{\text {Admin }}$ & 9.SOLPRO $_{\text {Repres }}$ & 12.SKNOW $_{\text {Lect }}$ & 20.SHARGOAL $_{\text {Lect }}$ \\
\hline TFE/LS & $2.17 \pm 0.11$ & $1.97 \pm 0.12$ & $2.67 \pm 0.14$ & $2.75 \pm 0.11$ \\
TFE/HS & $3.06 \pm 0.12$ & $2.83 \pm 0.13$ & $3.34 \pm 0.11$ & $3.59 \pm 0.09$ \\
IFE/LS & $1.67 \pm 0.15$ & $2.81 \pm 0.17$ & $3.22 \pm 0.16$ & $3.36 \pm 0.14$ \\
IFE/LS & $2.31 \pm 0.12$ & $3.70 \pm 0.09$ & $4.02 \pm 0.08$ & $4.17 \pm 0.07$ \\
\hline
\end{tabular}

\section{Discussion}

Results of this research are in line with those obtained by Gutiérrez-Cordero et al. [47] and Sá and Serpa [1], who evaluated the influence of organizational culture on educational styles and its effect on the level of satisfaction. RQ1 was not verified in this study. The students in the intensive style showed higher levels of relational coordination and, apart from this, the higher the level of relational coordination, the greater the satisfaction was found. Significant differences were observed in $65 \%$ of the organizational variables according to the educational style. 
The problem-solving variable related to student representatives is strategic in the intensive style, where students attend university on a reduced schedule and try to optimize their face-to-face time [36]. Likewise, when there is a problem, the student representatives are the first to be asked, since they are the link between the students and the rest of the profiles. Thus, De-Pablos-Heredero et al. [37] and Gallego et al. [5] indicate that a greater resolution of communication problems implies the improvement of educational quality.

Frequent communication with administrative officers obtained higher levels in the traditional style due to the coincidence of the work hours of the administrative officers and the attendance schedule of the students at the centre. According to Margalina et al. [36], poor communication on administrative processes generates uncertainty in the student and decreases satisfaction. An improvement in this variable in the intensive style could lead to an improvement in its quality.

RQ2 was verified in this study. Intensive education showed a higher level of satisfaction in $95 \%$ of the organizational variables. The maturity of the intensive style student allows greater commitment to their educational process [15]. Having greater autonomy and control over time and rhythm leads to a higher levels of satisfaction $[13,17,24,25]$. The intensive style impacts the same traditional training contents in a shorter period [18,20,22,23], making it more efficient for the student in need of flexibility and conciliation [14-17].

Mutual respect with lecturers was a strategic element for the improvement of $\mathrm{RC}$ and predominated in the intensive style. Respect between teacher and student is associated with better results based on more satisfactory relationships [4,5].

The intensive educational style presents a greater degree of collaboration between the student and their classmates. Those students with less time availability are more aware of their limitations and interact in shared learning [20]. The link of the student with the educational ecosystem is positively related to satisfaction $[3,6,12]$. Mutual respect between peers suggests better results in this educational style [5,36].

RQ3 was verified in this study. An organizational model was built through RC variables. Four groups were formed combining the educational styles and the two levels of satisfaction. The four groups show a positive relationship between RC and satisfaction. The groups with low satisfaction showed similar RC levels. The intensive style group with high satisfaction was the most differentiated. There is a greater flow of communication and relationship of the student with lectures and student representatives. The fact of attending class two days a week predisposes the student to greater communication with the teacher [3], solving specific doubts about the training content already studied by the student previously.

The RC model offers a basis for the study of higher education models, where there are diverse communication flows and a high degree of dependency on tasks $[4,5,36,37]$. Greater coordination with the organizational environment allows optimizing resources and provides greater satisfaction [1]. Higher levels of RC were associated with a higher level of student satisfaction [37].

The application of intensive face-to-face education allows this modality to achieve higher levels of student satisfaction by making a more efficient use of the time $[1,2,20,38]$. In this way, the implementation of organizational measures that improve communication between the student and the administration is proposed to the universities. Measures that enhance the knowledge and objectives shared between student and lectures and communication to solve problems with student representatives can lead to an improvement in educational quality.

This study has shown that students can take the same training contents in less faceto-face time without affecting their satisfaction, as long as there are adequate levels of coordination and communication. The scientific literature defends that, as more contingent factors demand a need for organizational action, the more important the application of relational coordination principles becomes [5,31,34,35]. Therefore, the application of relational coordination as an innovative organizational model for higher education could be transferable to other universities. This may be of interest for the configuration of future 
learning models in which the physical presence of the student in the educational centre must be considerably reduced.

\section{Limitations}

The methodology used makes it possible to compare two educational styles, which enables us to define face-to-face. Nevertheless, this work has some limitations. On the one hand, this study was carried out in a specific intensive program at a university considering students enrolled in agri-food profiles. In future research, the study could be extended to a sample of students belonging to different branches of knowledge to obtain a cross-sectional approach. On the other hand, quality was studied in terms of student satisfaction with the organisational model. Subsequent studies could associate quality with students' academic results, since their exploration was outside the scope of this study. Finally, given that this study focuses only on student satisfaction, the study from the perspective of the satisfaction of the rest of the university profiles (lecturers and administrative officers, among others) could be the object of study in future research.

\section{Conclusions}

In this research, differences between both educational styles were found, the intensive face-to-face style being the one that obtained the highest levels of RC and studen satisfaction.

A discriminant model with reduced number of variables was built and allowed for the identification of differences between face-to-face educational styles (traditional versus intensive). The obtained RC model was linked to the improvement of results. Problemsolving communication with students' representatives and shared knowledge and goals with lectures were the elements of success in this educational style. Frequent communication with administrative officers should be improved in the intensive style to increase performance. The proposed measures can be useful for the academic and administrative staff of the university that is committed to face-to-face education for adult students.

Face-to-face modality is an educational form that must be maintained to satisfy the educational demand of a specific profile of student with flexibility needs. Traditional face-toface education has been considered the most accepted and demanded model. However, it is possible to adjust this modality to achieve efficient intensive models that do not renounce the benefits provided by the contact of the student with the educational ecosystem. The findings of this research are useful to determine the appropriate duration of face-to-face education that improves satisfaction.

Future research could combine this high satisfaction face-to-face education model with the online modality to form a hybrid model, as an effective alternative smart education adjusted to the current situation.

Supplementary Materials: The following are available online at https:/ /www.mdpi.com/article/10 .3390/educsci11120820/s1, Table S1: Relational coordination survey.

Author Contributions: Conceptualization and methodology, all authors. Formal analysis, software, data curation, data processing, Y.G.T.; statistical analysis, C.C.-M. and C.B.; validation and investigation, C.D.-P.-H. and A.G.; supervision, A.G., C.D.-P.-H. and C.C.-M.; project administration, C.D.-P.-H. and A.G.; data acquisition, Y.G.T. and A.G. All authors have been involved in developing, writing, commenting, editing and reviewing the manuscript. All authors have read and agreed to the published version of the manuscript.

Funding: This research received no external funding.

Institutional Review Board Statement: Not applicable.

Informed Consent Statement: Not applicable.

Data Availability Statement: This is not applicable as the data are not in any data repository of public access, however if editorial committee needs access, we will happily provide them, please use this email: pa1gamaa@uco.es.

Conflicts of Interest: The authors declare no conflict of interest. 


\section{References}

1. Sá, M.J.; Serpa, S. The COVID-19 Pandemic as an Opportunity to Foster the Sustainable Development of Teaching in Higher Education. Sustainability 2020, 12, 8525. [CrossRef]

2. De Moura, V.F.; Alexandre de Souza, C.; Noronha Viana, A.B. The Use of Massive Open Online Courses (MOOCs) in Blended Learning Courses and the Functional Value Perceived by Students. Comput. Educ. 2021, 161, 104077. [CrossRef]

3. Amato, D.; de Jesús Novales-Castro, X. Utilidad para el aprendizaje de una modalidad educativa semipresencial en la carrera de Medicina. Investig. En Educ. Médica 2014, 3, 147-154. [CrossRef]

4. Gallego-Sánchez, M.C.; De-Pablos-Heredero, C.; Merodio, J.A.M. Coordinación relacional en la educación en línea. Interciencia Rev. Cienc. Tecnol. Am. 2015, 40, 869-874.

5. Gallego-Sánchez, M.C.; De-Pablos-Heredero, C.; Medina-Merodio, J.-A.; Robina-Ramírez, R.; Fernandez-Sanz, L. Relationships among Relational Coordination Dimensions: Impact on the Quality of Education Online with a Structural Equations Model. Technol. Forecast. Soc. Chang. 2021, 166, 120608. [CrossRef]

6. Paudel, P. Online Education: Benefits, Challenges and Strategies During and After COVID-19 in Higher Education. Int. J. Stud. Educ. 2021, 3, 70-85. [CrossRef]

7. Gherheș, V.; Stoian, C.E.; Fărcașiu, M.A.; Stanici, M. E-Learning vs. Face-To-Face Learning: Analyzing Students' Preferences and Behaviors. Sustainability 2021, 13, 4381. [CrossRef]

8. Tratnik, A.; Urh, M.; Jereb, E. Student Satisfaction with an Online and a Face-to-Face Business English Course in a Higher Education Context. Innov. Educ. Teach. Int. 2019, 56, 36-45. [CrossRef]

9. Lim, F. An Analysis of Synchronous and Asynchronous Communication Tools in E-Learning. 2017. Available online: https:/ /www.researchgate.net/publication/313673458_An_Analysis_of_Synchronous_and_Asynchronous_Communication_ Tools_in_e-Learning (accessed on 16 December 2021).

10. Escanés, G.; Herrero, V.; Merlino, A.; Ayllón, S. Deserción en educación a distancia: Factores asociados a la elección de modalidad como desencadenantes del abandono universitario. Virtualidad Educ. Cienc. 2014, 5, 45-55.

11. Cheng, X.; Chan, L.K.; Pan, S.-Q.; Cai, H.; Li, Y.-Q.; Yang, X. Gross Anatomy Education in China during the Covid-19 Pandemic: A National Survey. Anat. Sci. Educ. 2021, 14, 8-18. [CrossRef] [PubMed]

12. Lowenthal, P.R.; Snelson, C. In Search of a Better Understanding of Social Presence: An Investigation into How Researchers Define Social Presence. Distance Educ. 2017, 38, 141-159. [CrossRef]

13. Cho, H.J.; Levesque-Bristol, C.; Yough, M. International Students' Self-Determined Motivation, Beliefs about Classroom Assessment, Learning Strategies, and Academic Adjustment in Higher Education. High Educ. 2021, 81, 1215-1235. [CrossRef]

14. McNall, L.A.; Michel, J.S. The Relationship between Student Core Self-Evaluations, Support for School, and the Work-School Interface. Community Work Fam. 2017, 20, 253-272. [CrossRef]

15. Sprung, J.M.; Rogers, A. Work-Life Balance as a Predictor of College Student Anxiety and Depression. J. Am. Coll. Health 2020, 69. [CrossRef] [PubMed]

16. Balandya, E.; Sunguya, B.; Gunda, D.W.; Kidenya, B.; Nyamhanga, T.; Minja, I.K.; Mahande, M.; Mmbaga, B.T.; Mshana, S.E.; Mteta, K.; et al. Building Sustainable Research Capacity at Higher Learning Institutions in Tanzania through Mentoring of the Young Research Peers. BMC Med. Educ. 2021, 21, 166. [CrossRef] [PubMed]

17. Harwood, K.J.; McDonald, P.L.; Butler, J.T.; Drago, D.; Schlumpf, K.S. Comparing Student Outcomes in Traditional vs Intensive, Online Graduate Programs in Health Professional Education. BMC Med. Educ. 2018, 18, 240. [CrossRef] [PubMed]

18. Loton, D.; Stein, C.; Parker, P.; Weaven, M. Introducing Block Mode to First-Year University Students: A Natural Experiment on Satisfaction and Performance. Stud. High. Educ. 2020, 1-24. [CrossRef]

19. McLinden, M. Examining Proximal and Distal Influences on the Part-Time Student Experience through an Ecological Systems Theory. Teach. High. Educ. 2017, 22, 373-388. [CrossRef]

20. Samarawickrema, G.; Cleary, K. Block Mode Study: Opportunities and Challenges for a New Generation of Learners in an Australian University. Stud. Success 2021, 12, 13-23. [CrossRef]

21. Arranz, S.; Vázquez, M.; Peña, A.; Condori, C.; Almada, C.; Cabral, M.; Cáceres, P.; Salazar, S.; Martínez, S.; Tala, V. Retos de La Formación Online y Semipresencial En Universidades Tradicionalmente Presenciales. 2018. Available online: https://www.researchgate.net/publication/340574783_Retos_de_la_formacion_online_y_semipresencial_en_universidades_ tradicionalmente_presenciales (accessed on 16 December 2021).

22. Kim, J.O. Ongoing Speaking Anxiety of Korean EFL Learners : Case Study of a TOEIC Intensive Program. J. AsiaTEFL 2018, 15, 17-31. [CrossRef]

23. Huynh, N.; Burgess, A.; Wing, L.; Mellis, C. Anatomy by Whole Body Dissection as an Elective: Student Outcomes. J. Surg. Educ. 2020, 78, 492-501. [CrossRef]

24. Pozdnyakova, O.; Pozdnyakov, A. Adult Students' Problems in the Distance Learning. Procedia Eng. 2017, 178, 243-248. [CrossRef]

25. Sheail, P. Temporal Flexibility in the Digital University: Full-Time, Part-Time, Flexitime. Distance Educ. 2018, 39, 462-479. [CrossRef]

26. Araneda-Guirriman, C.; Sallán, J.G.; Pedraja-Rejas, L.; Rodríguez-Ponce, E. Percepciones sobre el perfil del estudiante universitario en el contexto de la educación superior de masas: Aproximaciones desde chile. Interciencia 2018, 43, 864-870.

27. Yilmaz, A.B. Distance and Face-To-Face Students' Perceptions Towards Distance Education: A Comparative Metaphorical Study. Turk. Online J. Distance Educ. 2019, 20, 191-207. [CrossRef] 
28. Romero, J.C.G.; Lugo, S.G. Apoyo percibido, resiliencia, metas y aprendizaje autorregulado en bachilleres. Rev. Electrónica De Investig. Educ. 2019, 21,1-10. [CrossRef]

29. Hsu, A.J.C.; Chen, M.Y.-C.; Shin, N.-F. From Academic Achievement to Career Development: Does Self-Regulated Learning Matter? Int. J. Educ. Vocat. Guid. 2021, 1-21. [CrossRef]

30. Zheng, L.; Li, X.; Chen, F. Effects of a Mobile Self-Regulated Learning Approach on Students' Learning Achievements and Self-Regulated Learning Skills. Innov. Educ. Teach. Int. 2018, 55, 616-624. [CrossRef]

31. Gittell, J.; Logan, C.; Cronenwett, J.; Foster, T.; Freeman, R.; Godfrey, M.; Vidal, D. Impact of Relational Coordination on Staff and Patient Outcomes in Outpatient Surgical Clinics. Health Care Manag. Rev. 2018, 45, 1. [CrossRef]

32. De-Pablos-Heredero, C.; Montes-Botella, J.L.; Soret-Los-Santos, I. Coordinación relacional y resultados empresariales: Aplicación a las prácticas de computación en la nube. Interciencia Rev. Cienc. Tecnol. Am. 2014, 39, 76-84.

33. De-Esteban, D. Relational Coordination in the Entrepreneurial Ecosystem. ESIC Mark. Econ. Bus. J. 2020, 135-158. [CrossRef]

34. Gittell, J. Supervisory Span, Relational Coordination and Flight Departure Performance: A Reassessment of Postbureaucracy Theory. Organ. Sci. 2001, 12, 468-483. [CrossRef]

35. Haider, S.; De-Pablos-Heredero, C.; De-Pablos-Heredero, M. A Three-Wave Longitudinal Study of Moderated Mediation Between High-Performance Work Systems and Employee Job Satisfaction: The Role of Relational Coordination and Peer Justice Climate. Front. Psychol. 2020, 11, 792. [CrossRef] [PubMed]

36. Margalina, V.M.; De-Pablos-Heredero, C.; Montes-Botella, J.L. Achieving Quality in E-Learning through Relational Coordination. Stud. High. Educ. 2017, 42, 1655-1670. [CrossRef]

37. De-Pablos-Heredero, C.; Carreño, L.; Checa-Morales, C.; Barba, C.; García, A. A Tool to Measure Quality from Student's Perceived Satisfaction. The Cases of Two Universities: Arcada UAS Finland and ESPAM MFL, Ecuador. 13th International Technology, Education and Development Conference, Project: INTED2019. 2019, pp. 9960-9965. Available online: https://library.iated.org/view/ DEPABLOSHEREDERO2019ATO (accessed on 21 October 2021).

38. McAuliffe, D. Challenges for Best Practice in Online Social Work Education. Aust. Soc. Work 2019, 72, 110-112. [CrossRef]

39. Nuestra Historia_UTEQ. Available online: https:/ / www.uteq.edu.ec/page/1 (accessed on 21 October 2021).

40. Checa, C.; De-Pablos-Heredero, C.; Torres, Y.G.; Montes-Botella, J.L.; Barba, C.; García, A. Focused Coordination Models towards Sustainability in Higher Education. Case of Quevedo State Technical University (Ecuador). Sustainability 2020, 12, 5760. [CrossRef]

41. Ecuador Categorías de Universidades LISTADO 2021. Available online: https://informacionecuador.com/listado-categorias-deuniversidades-ceaaces / (accessed on 15 July 2021).

42. Devlin, N.J.; Hansen, P.; Kind, P.; Williams, A. Logical Inconsistencies in Survey Respondents' Health State Valuations-a Methodological Challenge for Estimating Social Tariffs. Health Econ. 2003, 12, 529-544. [CrossRef]

43. Checa-Morales, C.; De-Pablos-Heredero, C.; Carreño, A.L.; Haider, S.; García, A. Organizational Differences among Universities in Three Socioeconomic Contexts: Finland, Spain and Ecuador. Relational Coordination Approach. Educ. Sci. 2021, 11, 445. [CrossRef]

44. The World Bank in Ecuador. Available online: https://www.worldbank.org/en/country/ecuador/overview (accessed on 21 October 2021).

45. Méndez, D.; Macía, F. Análisis factorial confirmatorio de la escala de actitudes hacia la estadística. Cuad. Neuropsicol. 2007, 1, 337-345.

46. Reips, U.-D.; Funke, F. Interval-Level Measurement with Visual Analogue Scales in Internet-Based Research: VAS Generator. Behav. Res. Methods 2008, 40, 699-704. [CrossRef] [PubMed]

47. Gutiérrez-Cordero, M.L.; Segovia-Vargas, M.J.; Escamilla, M.R. Análisis del Riesgo de Caída de Cartera en Seguros: Metodologías de "Inteligencia Artificial” vs “Modelos Lineales Generalizados. " Econ. Inf. 2017, 407, 56-86. [CrossRef]

48. Legendre, P.; Legendre, L. Chapter 11-Canonical Analysis. In Developments in Environmental Modelling; Legendre, P., Legendre, L., Eds.; Numerical Ecology; Elsevier: Amsterdam, The Netherlands, 2012; Volume 24, pp. 625-710.

49. Cea D'Ancona, M.Á. Análisis Discriminante; Cuadernos Metodológicos; CIS Centro de Investigaciones Sociológicas: Madrid, Spain, 2016; ISBN 978-84-7476-707-0.

50. Lee, S.; Yu, J. Discriminant Model of BIM Acceptance Readiness in a Construction Organization. KSCE J. Civ. Eng. 2017, 21, 555-564. [CrossRef] 